\title{
Association between VEGF-2578 C>A Polymorphism with Gastric Premalignant Lesion in Gastritis with Helicobacter
}

\author{
Mario Eka Paskah Sinulingga ${ }^{1}$, Gontar Alamsyah Siregar ${ }^{2}$, Ilhamd², \\ Dharma Lindarto ${ }^{3}$
}

\author{
${ }^{1}$ Department of Internal Medicine, Faculty of Medicine, Sumatera Utara University, Medan \\ ${ }^{2}$ Division of Gastroenterohepatology, Department of Internal Medicine, Faculty of Medicine, Sumatera Utara \\ University, Medan \\ ${ }^{3}$ Division of Metabolic and Endocrinology, Department of Internal Medicine, Faculty of Medicine, Sumatera \\ Utara University, Medan
}

Corresponding Author: Gontar Alamsyah Siregar

\begin{abstract}
Introduction: Gastric cancer is one of the most common causes of cancer-related deaths worldwide. Many epidemiological studies have shown several risk factors associated with the development of gastric cancer, including gastritis. The most common cause of gastritis is H. pylori infection. In the H.pylori-infected mucosa, there was a significant increase in VEGF levels. Several SNPs are thought to be involved in the etiology of malignancy, one of which is the VEGF-2578C > A polymorphism.
\end{abstract}

Methods: A cross sectional study was conducted in Medan with $59 \mathrm{H}$. Pylori gastritis patients. Endoscopic examination was performed to assess the gastric mucosa. H.pylori status was determined by examination of Urea breath Test (UBT) and Campylobacter Like Organism (CLO) test followed by histopathological studies evaluating the presence of changes to pre-malignant lesions such as chronic atrophic gastritis, intestinal metaplasia, intestinal dysplasia. Genotype analysis was carried out using Polymerase Chain Reaction (RT-PCR). Data analysis was carried out by univariate and bivariate

Result: Of the 59 patients with H. pylori gastritis, $35.8 \%$ of patients showed premalignant lesions. The majority of premalignant lesions had a CC genotype $(37.9 \%, \mathrm{n}=11)$, but there was no significant relationship between the VEGF-2578 C>A polymorphism and the incidence of gastric premalignant lesions.
Conclusion: Based on this study, the VEGF $2578 \mathrm{C}>\mathrm{A}$ polymorphism was not associated with gastric premalignant lesions in $\mathrm{H}$. pylori gastritis patients.

Keyword: Polymorphism VEGF, VEGF 2578C > A, Premalignant lesions, H. Pylori

\section{INTRODUCTION}

Gastric cancer is the fifth most common cancer and the third leading cause of cancer-related death. Around 1 million new cases were found in 2018 with a death toll of 783,000 deaths ${ }^{1}$. The incidence and mortality of gastric cancer varies greatly by region and is related to diet and infection by Helicobacter pylori. ${ }^{2}$.

The process of gastric cancer is a continuous process that starts from chronic gastritis which develops into gastric premalignant lesions and gastric cancer. Various evidences show that Helicobacter pylori (H. pylori) infection is closely associated with the development of gastroduodenal diseases such as peptic ulcer, chronic atrophic gastritis and gastric cancer. 3 . H. pylori play a role in the pathogenesis of gastric malignancy through the activation of host angiogenesis. In the H.pyloriinfected mucosa, there was a significant increase in VEGF levels. ${ }^{4}$. An increase in VEGF triggers an increase in the number of 
new blood vessels. Angiogenesis formed by the role of VEGF is required for the development and spread of these tumors 5

Vascular Endothelial Growth Factor (VEGF) is the most potent stimulus for neoangiogenesis among other angiogenic factors. VEGF is excreted as a result of increased expression and release of gastrin from antrum $\mathrm{G}$ cells. VEGF can bind to the VEGF receptor (VEGFR) to trigger multiple cellular signaling pathways that can inhibit apoptosis, stimulate endothelial cell survival, and recruit endothelial precursor cells from the bone marrow to sites of angiogenesis. Capillary permeability also increases as a result of this angiogenesis ${ }^{6}$.

The VEGF gene is located on chromosome 6 which is located at $6 \mathrm{p} 21.1$ which consists of 8 exons separated by 7 introns and is highly polymorphic (has 140 variants). SNP is a genetic variation that occurs when a single nucleotide, namely adenine $(\mathrm{A})$, thymine $(\mathrm{T})$, cytosine $(\mathrm{C})$ or guanine $(\mathrm{G})$ changes in the genome sequence and is inherited. VEGF gene polymorphisms can be found in many different locations and have an influence on the risk of cancer development ${ }^{7}$

Several SNPs have been implicated in the etiology of malignancy, one of which is the VEGF-2578C $>\mathrm{A}$ polymorphism which is located in the promoter region of the VEGF gene. This polymorphism is closely related to the increased expression of VEGF which can affect the production of VEGF protein. In a previous study, there was an increased risk of premalignant lesions in $\mathrm{H}$. pylori gastritis patients with VEGF-634 G>C polymorphisms in the GG and GC8 genotypes. The $936 \mathrm{C}>\mathrm{T}$ polymorphism also increases the risk of increasing the degree of atrophy in gastritis patients with $\mathrm{CC}$ genotype 8 . According to research by Liu, $W$ et al, there is no significant relationship between the VEGF 2578 polymorphism on the development, risk, prognostic and survival of gastric cancer 9 How the influence of genetics on the development of gastric premalignant lesions in $\mathrm{H}$. pylori gastritis patients is an interesting topic to study. As far as researchers know, there are no studies that directly link the VEGF $-2578 \mathrm{C}>\mathrm{A}$ polymorphism with gastric premalignant lesions in $\mathrm{H}$. pylori gastritis patients. Therefore, this author wrote about the relationship between the VEGF-2578C $>$ A polymorphism and gastric premalignant lesions in $\mathrm{H}$. pylori gastritis patients.

\section{METHODS}

The number of respondents in this study amounted to 59 respondents. This research was conducted at H.Adam Malik Hospital and Jejaring Hospital and was conducted in 2020. The sampling in this study was based on consecutive sampling that met the inclusion criteria and exclusion criteria.

Participants in this study were patients with $\mathrm{H}$. pylori gastritis positive (+) based on anamnesis, physical examination and supporting examinations such as UBT examination, CLO examination. Included in the inclusion criteria in this study were: age 18 years, patients diagnosed with $\mathrm{H}$. pylori gastritis, and patients who were cooperative and willing to participate. The exclusion criteria in this study were: Patients who had received $\mathrm{H}$. pylori eradication therapy in the last 6 months or were on antibiotic therapy commonly used in eradication therapy, Consumption of Proton Pump Inhibitors, H2 receptor antagonists for the past 1 month, No systemic disease and violence and pregnant women. Endoscopic examination was performed to assess the gastric mucosa, followed by histopathological studies evaluating the presence of changes to premalignant lesions such as chronic atrophic gastritis, intestinal metaplasia, and intestinal dysplasia. Genotype analysis was performed using Polymerase Chain Reaction (RT-PCR).

Univariate and bivariate analysis were performed. Univariate analysis to determine the percentage of VEGF -2578 $\mathrm{C}>\mathrm{A}$ polymorphism and sociodemographic character. Bivariate analysis to analyze the presence of gastric premalignant lesions 
against the VEGF-2578 C>A polymorphism in patients with Helicobacter pylori gastritis. Data were analyzed using SPSS by performing Chi Square Test. P value $<0.05$ was considered significant.

\section{RESULT}

\section{Characteristics of Respondents}

This study involved 59 Helicobacter pylori gastritis patients. Table 3.1 shows patient demographics. Gastric premalignant lesions were found in $41.3 \%$ of men and $30 \%$ of women. It can also be seen in the elderly population $>50$ years $(39.4 \%)$, low education level (38.9\%), alcohol consumption $(53.3 \%)$, concurrent $\mathrm{H}$. pylori infection $(35.6 \%)$ and positive family history of gastric cancer $(75 \%)$. Based on this study, H. Pylori gastritis patients who had a history of consuming alcohol turned out to have a significant relationship with the occurrence of gastric premalignant lesions ( $\mathrm{p}$ 0.018). However, other characteristics of $\mathrm{H}$. pylori gastritis sufferers such as age ( $p$ 0.402), family history of gastric cancer ( $\mathrm{p}$ 0.124), smoking habits ( $\mathrm{p}$ 0.303 ), education (p 0.208) and overweight (p 0.217) did not have a significant relationship. Significant for the occurrence of gastric premalignant lesions.

\begin{tabular}{|c|c|c|c|c|}
\hline \multirow[t]{2}{*}{ Variable } & \multicolumn{2}{|c|}{ Premalignant lesion } & \multirow[t]{2}{*}{ Total } & \multirow[t]{2}{*}{$\mathbf{p}$} \\
\hline & Yes & No & & \\
\hline $\begin{array}{l}\text { sex } \\
\text { male } \\
\text { female }\end{array}$ & $\begin{array}{l}12(41.3 \%) \\
9(30 \%)\end{array}$ & $\begin{array}{l}17(58.7 \%) \\
21(70 \%)\end{array}$ & $\begin{array}{l}29(100 \%) \\
30(100 \%)\end{array}$ & 0.361 \\
\hline $\begin{array}{l}\text { Age } \\
\geq 50 \text { years } \\
<50 \text { years }\end{array}$ & $\begin{array}{l}15(39.4 \%) \\
6(28.5 \%)\end{array}$ & $\begin{array}{l}23(60.6 \%) \\
15(71.5 \%)\end{array}$ & $\begin{array}{l}38(100 \%) \\
21(100 \%)\end{array}$ & 0.402 \\
\hline $\begin{array}{l}\text { Education } \\
\text { Low } \\
\text { High } \\
\end{array}$ & $\begin{array}{l}6(46.1 \%) \\
15(41.6 \%)\end{array}$ & $\begin{array}{l}7(53,9 \%) \\
31(58.4 \%) \\
\end{array}$ & $\begin{array}{l}13(100 \%) \\
36(100 \%)\end{array}$ & 0.280 \\
\hline $\begin{array}{l}\text { Overweight } \\
\text { Yes } \\
\text { No }\end{array}$ & $\begin{array}{l}7(26.9 \%) \\
14(42.4 \%)\end{array}$ & $\begin{array}{l}19(73.1 \%) \\
19(57.6 \%)\end{array}$ & $\begin{array}{l}26(100 \%) \\
33(100 \%)\end{array}$ & 0.217 \\
\hline $\begin{array}{l}\text { Alcohol Consumption } \\
\text { Yes } \\
\text { No } \\
\end{array}$ & $\begin{array}{l}7(70 \%) \\
14(28.5 \%) \\
\end{array}$ & $\begin{array}{l}3(30 \%) \\
35(71.5 \%) \\
\end{array}$ & $\begin{array}{l}10(100 \%) \\
49(100 \%) \\
\end{array}$ & $0.018 *$ \\
\hline $\begin{array}{l}\text { Smoker Status } \\
\text { Moderate to High } \\
\text { Absent to Mild }\end{array}$ & $\begin{array}{l}6(27.2 \%) \\
15(40.5 \%) \\
\end{array}$ & $\begin{array}{l}16(72.8 \%) \\
22(59.5 \%)\end{array}$ & $\begin{array}{l}22(100 \%) \\
37(100 \%) \\
\end{array}$ & 0.303 \\
\hline $\begin{array}{l}\text { Family history of gastric cancer } \\
\text { Yes } \\
\text { No }\end{array}$ & $\begin{array}{l}3(75 \%) \\
18(22.9 \%)\end{array}$ & $\begin{array}{l}1(25 \%) \\
37(77.1 \%)\end{array}$ & $\begin{array}{l}4(100 \%) \\
55(100 \%)\end{array}$ & 0.124 \\
\hline
\end{tabular}

3.2 Association between VEGF 2578 C>A polymorphism with gastric premalignant lesions

Genotyping tests were performed to find the relationship between VEGF -2578 $\mathrm{C}>\mathrm{A}$ and the presence of gastric premalignant lesions (table 4.2). In VEGF -
$2578 \mathrm{C}>\mathrm{A}$, the majority of premalignant lesions had a CC genotype $(37.9 \%, \mathrm{n}=11)$, but there was no significant relationship between the VEGF $-2578 \quad \mathrm{C}>\mathrm{A}$ polymorphism and the incidence of gastric premalignant lesions.

\begin{tabular}{|l|l|l|l|l|}
\hline VEGF 2578 C>A & Premalignant lesion & Total & P \\
\hline Polimorfisme & Yes & No & & \\
\hline CC & $11(37,9 \%)$ & $18(62,1 \%)$ & $29(100 \%)$ & \\
CA & $8(38 \%)$ & $13(62 \%)$ & $21(100 \%)$ & 0.544 \\
AA & $2(22.2 \%)$ & $7(77,8 \%)$ & $9(100 \%)$ & \\
\hline
\end{tabular}

\section{DISCUSSION}

VEGF is an important factor in angiogenesis, especially in malignancies. VEGF plays a role in tumor neovascularization which functions to increase the nutritional and oxygen requirements needed for the survival of tumor cells. VEGF transcription is triggered by hypoxia and various growth signals. Endothelial cells stimulated by VEGF 
migrate and proliferate leading to increased permeability and vascular growth 10,11 .

In this study, we evaluated $59 \mathrm{H}$. pylori gastritis patients in Medan, Indonesia, to determine whether there were premalignant gastric lesions. Based on our findings, we observed several baseline characteristics that were significantly associated with the finding of gastric premalignant lesions. Based on this study, patients with $\mathrm{H}$. Pylori gastritis who had a history of consuming alcohol turned out to have a significant relationship with the occurrence of gastric premalignant lesions (p 0.018). However, other characteristics of $\mathrm{H}$. pylori gastritis sufferers such as age ( $\mathrm{p}$ 0.402 ), family history of gastric cancer ( $p$

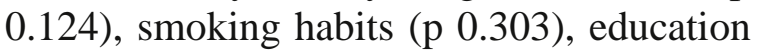
(p 0.208) and overweight ( $\mathrm{p}$ 0.217) did not have a significant relationship, significant for the occurrence of gastric premalignant lesions.

The current study also evaluated various genotypes and allelic involvement in the SNPs of VEGF -2578C>A. Previous evidence suggests several potentially functioning SNPs are associated with malignancies including gastric cancer. Apart from the potential association, our genotypic analysis found no significant association between the VEGF -2578C>A polymorphism and gastric premalignant lesions. It's similar from Xia HZ. The study et al in 311 gastric cancer patients with gastric carcinoma in China also found that there was no significant association between the distribution of the genotype, allele, and haplotype of VEGF $2578 \mathrm{C}>\mathrm{A}^{12}$.

A meta-analysis study in China conducted by Zhuang $\mathrm{M}$ et al on 2,281 cases and 2,200 controls derived from 9 casecontrol studies in which VEGF $2578 \mathrm{C}>\mathrm{A}$ found that there was no association with an increased risk of gastric cancer ${ }^{13}$. A similar case-control study involving 540 high-risk individuals in the Chinese population, Ke et al (2008) analyzed 4 SNPs including VEGF $-2578 \mathrm{C}>\mathrm{A}$ occurring in the promoter region. The study reported no significant association between the above-mentioned
SNPs and the risk of developing gastric cancer, either involving a single locus or a combination of haplotype ${ }^{14}$. The cohort by Tzanakis et al (2006) of 100 gastric cancer patients in Greece reported that the VEGF genotype polymorphism $-2578 \mathrm{C}>\mathrm{A}$ has a genotype consisting of CC 32\%, CA $39 \%$ and AA 29\% 15. In this study, the distribution of VEGF $2578 \quad \mathrm{C}>\mathrm{A}$ polymorphisms was the most in $\mathrm{H}$ pylori gastritis patients with gastric premalignant lesions between $\mathrm{CC}$ as much as $37.9 \%$, followed by CA $38 \%$ and AA $22.2 \%$

The most recent meta-analysis was conducted in 2018 involving multiple studies of several functional SNPs potentially associated with gastric cancer. Among several identified SNPs, this study analyzed two published studies of VEGF 2578C > A 9. Similar to our findings, a meta-analysis reported that VEGF -2578C > A was not associated with gastric cancer.

VEGF $2578 \mathrm{C}>\mathrm{A}$ located in the promoter region and DNA sequence variations in the promoter region of the VEGF gene have previously been associated with differences in VEGF gene and protein expression. The VEGF $2578 \mathrm{C}>\mathrm{A}$ SNP in the promoter region of the VEGF gene has been associated with the expression of VEGF protein in peripheral blood mononuclear cells ${ }^{16}$ VEGF protein expression in peripheral blood is induced by hypoxia by macrophages with a complex inflammatory process ${ }^{17}$. Hypoxia in tumors is the main driving force. induces tumor angiogenesis and activates hypoxia-induced expression of factor-1 (HIF-1), which then induces the expression of various proangiogenic factors, including vascular endothelial growth factor (VEGF) and vascular endothelial growth factor receptor (VEGFR), in cancer cells 18. Mechanisms The promoter region of VEGF 2578 is still unclear and not fully understood related to the risk of gastric cancer and needs further research. 


\section{CONCLUSION}

a. There is a significant relationship in $\mathrm{H}$ pylori gastritis patients who consume alcohol to the risk of gastric premalignant lesions.

b. There is no significant relationship between the VEGF $-2578 \quad \mathrm{C}>\mathrm{A}$ polymorphism on the occurrence of gastric premalignant lesions.

\section{ACKNOWLEDGEMENT}

The authors gratefully acknowledge that the present research is supported by the Ministry of Research and Technology and Higher Education Republic of Indonesia. The support is under the research grant DRPM (Direktorat Riset dan Pengabdian Masyarakat).

\section{Conflict of Interest: None}

\section{Source of Funding: None}

\section{Ethical Approval: Approved}

\section{REFERENCES}

1. Bray F, Ferlay J, Soerjomataram I, Siegel RL, Torre LA, Jemal A. Global cancer statistics 2018: GLOBOCAN estimates of incidence and mortality worldwide for 36 cancers in 185 countries. CA: A Cancer Journal for Clinicians. 2018 Nov;68(6):394424.

2. Rawla P, Barsouk A. Epidemiology of gastric cancer: global trends, risk factors and prevention. pg. 2019;14(1):26-38.

3. Holleczek B, Schöttker B, Brenner $\mathrm{H}$. Helicobacter pylori infection, chronic atrophic gastritis and risk of stomach and esophagus cancer: Results from the prospective population-based ESTHER cohort study. Int J Cancer. 2020 May 15;146(10):2773-83.

4. Siregar G, Sari D, Sungkar T. Serum VEGF Levels in Helicobacter pylori Infection and Correlation with Helicobacter pylori cagA and vacA Genes. Open Access Maced J Med Sci. 2017 Mar 19;5(2):137-41.

5. Macedo F, Ladeira K, Longatto-Filho A, Martins SF. Gastric Cancer and Angiogenesis: Is VEGF a Useful Biomarker to Assess Progression and Remission?. J Gastric Cancer. 2017;17(1):1.

6. Chekhonin VP, Shein SA, Korchagina AA, Gurina OI. VEGF in Tumor Progression and Targeted Therapy. CCDT. 2013 May 1;13(4): 423-43.

7. Eng L, Liu G. VEGF pathway polymorphisms as prognostic and pharmacogenetic factors in cancer: a 2013 update. Pharmacogenomics. 2013 Oct; 14(13): 1659-67.

8. Siregar, GA, Parwati, I., Achmad, TH, \& Syukriani, YF (2018). Association between vegf-634 G>C gene polymorphism with gastric premalignant lesions and serum vegf levels in helicobacter pylori gastritis patients. Open Access Macedonian Journal of Medical Sciences, 6 (8), 1328-1334. https://doi.org/10.3889/oamjms.2018.266

9. Liu W, Dong Z, Hu R, Wang C. Association of Vascular Endothelial Growth Factor (VEGF) Gene Polymorphisms With Gastric Cancer and Its Development, Prognosis, and Survival. Technol Cancer Res Treat. 2018 Jan;17:153303461775381.

10. Hicklin DJ, Ellis LM. Role of the Vascular Endothelial Growth Factor Pathway in Tumor Growth and Angiogenesis. JCO. 2005 Feb 10;23(5):1011-27.

11. Huachuan $Z$ et al (2006) . Expressions of MMP-2, MMP-9 and VEGF are Closely Linked to Growth, Invasion, Metastasis and Angiogenesis of Gastric Carcinoma Anticancer Research; 26: 35793584

12. Xia H, Wu Q, Du W. Association of Genetic Variants of VEGF gene with Gastric Carcinoma Risk. J Biochip Tissue chip. 2011;01(01)

13. Zhuang M, Peng Z, Wang J, Su X. Vascular endothelial growth factor gene polymorphisms and gastric cancer risk: a meta-analysis. J BUON. 2017 May-Jun; 22(3):714-24.

14. Ke Q, Liang J, Wang L, Hu Z, Jin G, Zhou $\mathrm{Y}$, et al. Potentially functional polymorphisms of the vascular endothelial growth factor gene and risk of gastric cancer. Mol Carcinog. 2008 Aug;47(8):64751.

15. Tzanakis N, Gazouli M, Rallis G, Giannopoulos G, Papaconstantinou I, Theodoropoulos G, et al. Vascular endothelial growth factor polymorphisms in gastric cancer development, prognosis, and 
Mario Eka Paskah Sinulingga et.al. Association between VEGF-2578 C>A polymorphism with gastric premalignant lesion in gastritis with helicobacter.

survival. J Surg Oncol. 2006 Dec 1;94(7): 624-30.

16. Prior SJ, Hagberg JM, Paton CM, Douglass LW, Brown MD, McLenithan JC, et al. DNA sequence variation in the promoter region of theVEGFgene impactsVEGFgene expression and maximal oxygen consumption. American Journal of Physiology-Heart and Circulatory Physiology. 2006 May;290(5):H1848H1855.

17. Ma F, Zhang B, Ji S, Hu H, Kong Y, Hua Y, et al. Hypoxic Macrophage-Derived VEGF Promotes Proliferation and Invasion of
Gastric Cancer Cells. Dig Dis Sci. 2019 Nov;64(11):3154-63.

18. Hsieh H, Tsai M. Tumor progressiondependent angiogenesis in gastric cancer and its potential application. WJGO. 2019 Sep 15;11(9):686-704.

How to cite this article: Sinulingga MEP, Siregar GA, Ilhamd et.al. Association between VEGF-2578 C>A polymorphism with gastric premalignant lesion in gastritis with helicobacter. International Journal of Research and Review. 2021; 8(8): 13-18. DOI: https:// doi.org/10.52403/ijrr.20210803 